\title{
VERDUM, Ricardo. Povos indígenas, meio ambiente e políticas públicas: uma visão a partir do orçamento indigenista federal. Rio de Janeiro: E-papers, 2017. 208 p.
}

Lucas Gonçalves Brito*

*Universidade Federal do Rio Grande do Sul - Porto Alegre, RS, Brasil Doutorando em Antropologia Social (bolsista Capes)

lucasgb25@gmail.com 
O contexto histórico no qual se insere a pesquisa de Verdum pode ser caracterizado como um período de recrudescimento da violência perpetrada pelo agronegócio em relação aos povos indígenas, bem como um momento em que a complexidade dos processos implicados no sistema capitalista global somente é apreensível por uma análise cuidadosa. O livro de Verdum consegue abranger conjuntura e historicidade por meio de dados quantitativos e alcança uma sutileza descritiva que poder-se-ia atribuir, talvez, à sua longa experiência de pesquisa de campo.

Um dos destaques é a introdução a aspectos mais salientes - e outros assaz intricados - das políticas públicas destinadas aos povos indígenas e o esclarecimento acurado quanto às falhas apresentadas pelo Estado no trato dispensado aos direitos diferenciados dessas populações. Pode-se definir a temática do livro como uma crítica contundente e bem-fundamentada às políticas orçamentárias e ação indigenista do governo federal no período de 2003 a 2012.

Os três mandatos presidenciais do PT, abarcados pelo recorte temporal da análise, encontraram "desafios da governabilidade", como chama Verdum, e que se encaixaram nesse processo como um imperativo de "equilibrar os interesses em conflito que se produziram entre atores estratégicos para ambas as gestões, tanto aliados como adversários" (p. 11). Um exemplo seria os impasses na homologação da Terra Indígena Raposa/Serra do Sol, que refletem questões político-partidárias dos mandatos petistas - o governo não queria se indispor com o Congresso Nacional e com os setores desenvolvimentistas do agronegócio e mineração que sustentavam sua governabilidade (p. 37).

Como mostra Verdum, o período prometia transformações no que tange aos direitos indígenas. Entretanto, o que se revelou, em parte, foi a repetição de um habitus indigenista que, fundado sobre noções e práticas tutelares, não respeita a autonomia, protagonismo e autodeterminação indígenas. Um dos maiores desafios do movimento indígena seria, nesse sentido, o de justamente alcançar maior autonomia sobre os recursos naturais e o conhecimento para usufruto de seus territórios. ${ }^{1}$ Para tal, vê-se a necessidade de criar e sustentar

1 Cabe a ressalva de que nem todos os povos ameríndios concebem as terras como "natureza-objeto" a ser explorada, embora possam se apropriar da linguagem modernista característica do Estado. Sob outro aspecto, a obtenção da legitimidade sobre os territórios historicamente habitados por indígenas, através de concessões nos marcos legais dos Estados nacionais, não garante a continuidade do modus vivendi autônomo dos povos. Como García Hierro e Surrallés (2004) 
meios de inserção política de indígenas nos mecanismos institucionais, que garantiriam o atendimento das necessidades próprias, uma vez que, talvez, os projetos e programas governamentais seriam informados com ideias e objetivos dos povos indígenas.

O quadro fornecido pelo autor conduz a uma reflexão sobre a falta de atenção às especificidades ambientais, educacionais, terapêuticas e até mesmo alimentares dos povos indígenas. Essa dificuldade técnico-científica, engendrada por um regime de conhecimento colonialista que tende à supressão da diferença cultural por meio de ações truculentas, alinha-se com a racionalidade de uma versão hipermoderna e doentia de capitalismo.

A diversidade de problemáticas levantadas por cada capítulo não traduz reducionismo. Distintamente, o livro consegue abordar de modo arguto as questões propostas nos três eixos/partes que o conformam - Orçamento e Políticas Públicas, Meio Ambiente e Mulheres Indígenas. Deve-se ter em vista o caráter informativo dos textos reunidos, os quais, em sua maioria, foram divulgados para um público amplo, há pelo menos cinco anos, no boletim Orçamento \& Política Socioambiental. Enquanto documento de cariz histórico, o livro fornece conteúdo e motes para reflexões relevantes, especialmente no sentido de erros e acertos que ao movimento indígena caberia aquilatar precisamente.

Um destaque, como exemplo, é o capítulo 5, que enfoca "Os povos indígenas na reforma política". Trata-se de um texto breve, mas que demonstra uma complexidade enorme, e, ainda que sucintamente, registra algumas proposições da maior importância para a inserção de representantes indígenas na vida política institucionalizada e para a superação, pelo movimento indígena, do regime tutelar que marca a atuação do Estado.

A ideia de um "parlamento indígena nacional" vinha se delineando, desde meados dos anos 2000, como uma instância macrorregional de diálogo do movimento indígena para além de articulações localistas (p. 39). Em 2005, em seminário organizado pelo Fórum Nacional de Participação Popular, a Reforma Política no Brasil foi discutida e foi semeada a proposição de um Conselho Indígena articulado ao Congresso Nacional, que funcionasse dentro de um sistema específico de escolha de representantes indígenas. Não obstante a tentativa de

apontam, é importante que esses modos de vida sejam constituídos por "visões territoriais" e "modelos produtivos próprios" aos indígenas. 
consolidação desse sistema, o movimento indígena encontrou entraves internos e desafios no relacionamento com os órgãos do Estado, com as assessorias e agências de cooperação internacional (p. 75). Verdum não explora quais seriam essas dificuldades, deixando-nos a possibilidade de explorar hipóteses. O que as noções e práticas tutelares que o Estado reproduz em relação aos movimentos indígenas teriam que ver com os entraves encontrados por eles em participarem democraticamente da vida política institucionalizada no Brasil?

O livro também explicita uma outra realidade vivida por povos indígenas no Brasil: direitos consuetudinários e constitucionais são frequentemente desrespeitados, tanto por parte de governos como por parte da sociedade envolvente. Não é diferente, infelizmente, no que tange ao meio ambiente.

A exploração predatória de "recursos naturais" está, conforme Verdum, imbricada em uma "visão economicista e mercantil que se expande e se projeta de forma acelerada sobre a natureza e os territórios indígenas" (p. 132). As terras indígenas não são poupadas da fome desenvolvimentista que assola o Brasil no contexto da expansão da monocultura e exportação de produtos agrícolas, da mineração, das atividades madeireiras e construção de hidrelétricas.

O livro de Verdum merece ser lido, ainda, pelas formulações que correlacionam processos macroestruturais aos processos que atravessam o movimento indígena. É nesse sentido que se compreende como as transformações recentes da economia sul-americana, no que tange ao aumento do desenvolvimentismo baseado em exportação de produtos primários, aconteceram, pari passu, a mudanças no movimento indígena. Estando inseridos em modos de vida estreitamente ligados ao "ambiente natural", povos indígenas recebem a alcunha de "povos tradicionais" e passam, em alguns momentos, a serem enredados em um etnodesenvolvimento nem sempre reflexivo, engolfado pelo que hoje se tem chamado de "mercado verde".

A exploração dos recursos em terras indígenas, bem como a apropriação mercadológica de seus conhecimentos, levanta a questão da propriedade intelectual e da necessidade de mecanismos de consulta prévia, sendo que estes últimos, aparentemente, servem para garantir a participação das populações nos lucros advindos dos negócios conduzidos pelo Estado.

Como se vê, a força transformativa das premissas cosmo-ontológicas dos conhecimentos indígenas - tal como a relação um tanto quanto mais respeitosa com o ambiente - pode parecer diminuída pela inserção problemática 
de indígenas em certa lógica monetária. ${ }^{2}$ Tal racionalidade exploratória, que empresta algumas formações discursivas da biodiversidade para a defesa de um "desenvolvimento sustentável", redunda, como mostra Escobar (1998), em uma espécie de bioimperialismo globalocêntrico desastroso e reitera práticas colonizadoras, enriquecedoras, porém ambientalmente devastadoras. Outrossim, enfim, a noção de desenvolvimento sustentável apresenta uma contradição de termos.

\section{Referências}

ESCOBAR, A. Whose knowledge, whose nature? Biodiversity, conservation, and the political ecology of social movements. Journal of Political Ecology, Tucson, v. 5, p. 53-82, 1998.

GARCÍA HIERRO, P.; SURRALLÉS, A. Introducción. In: SURRALLÉS, A.; GARCÍA HIERRO, P. (Ed.). Tierra adentro: territorio indígena e percepción del entorno. Copenhague: IWGIA, 2004. p. 9-22.

2 Sob outro aspecto, existe a necessidade de recursos para projetos próprios, como aqueles propostos pelas redes de mulheres indígenas visando a soberania alimentar, a conservação de biodiversidade, o incremento da educação indígena e a atenção etnicamente orientada à saúde, tendo como condição sine qua non o reconhecimento e demarcação de terras indígenas (ver capítulos 16, 17 e 18).

Esta obra está licenciada com uma Licença Creative Commons - Atribuição 4.0 Internacional This work is licensed under a Creative Commons Attribution 4.0 International License. 